\title{
E-Governance Initiatives for the Socio- Economic Empowerment of Women to Transform the Uttar Pradesh State of India
}

\author{
Dr. Saurabh Gupta ${ }^{1}$, Sameer Rajan ${ }^{2}$ \\ ${ }^{1}$ Scientist-'F' \& State Informatics Officer, \\ ${ }^{2}$ Scientist-'B' \& District Informatics Officer National Informatics Centre, Ministry of Electronics and I.T., Govt. \\ of India NIC- Uttar Pradesh Unit, (India)
}

\begin{abstract}
If Uttar Pradesh (UP) state of India were a country, it would be the 5th most populous country in the world. As per details from Census India 2011, Uttar Pradesh has population of 19.98 Crores of which the female population is $47.6 \%$ and the female literacy rate is only $59.26 \%$ which is below than India's literacy rate. The status of women in UP is not appreciable. The empowerment and advancement of the women are the demand of time because women contribution in all the fields is required for the sustained, affirmative transformation and growth of the society. But there are various barriers to women empowerment and advancement like poverty, low education levels, unemployment, patriarchal attitude and gender based atrocity against women. The Government of Uttar Pradesh (GoUP) has taken initiatives for women empowerment and advancement so that the women can contribute to build up the nation. These initiatives are required to do Business Process Re-engineering of the Government functions.

In this paper, we study and highlight the socio- economic status of women, and the various Government Process Re-engineering tools in the form of E-Governance initiatives which are implemented in the state for the women empowerment.
\end{abstract}

Keywords: Census India, E-Governance, Empowerment, Government Process Re-engineering, GoUP.

\section{INTRODUCTION}

As per Census India 2011, total population of Uttar Pradesh is $199,812,341$ of which male and female are $104,480,510$ and $95,331,831$ respectively. The $47.6 \%$ of total population is female and the literacy rate reaches only to $59.26 \%$. Female population is still lagging behind due to the various reasons like poverty, low education levels, unemployment, patriarchal attitude and gender based atrocity against women. As per World Bank, $70 \%$ of the population is below poverty line (BPL). Poverty is widespread in UP. The pace of poverty reduction has been slower than other states of the country. Due to the poverty and male dominance society, women face the bad consequences of it in the form of domestic violence, dowry issues, starvation etc. The education is the key component of human development and it is the right of every child. Education levels are closely related with indicators of human development like fertility, mortality rates, etc. The female literacy rate is quite low. Female education is necessary to create an educative environment in the society. Statistically, Women's work is less visible in the society. Majority of the women involve in the non paid work which includes domestic chores like cooking, cleaning, child care and elders. Employment opportunities seem to be much lower for women in the state which restrict their economic empowerment. Female work participation rates are higher in the poorer regions of
Bundelkhand and Eastern UP. Restriction on women's mobility, child care responsibility, ideology of female seclusion, vulnerability to abuse, low access to information and mass media, low literacy, assumption that women's work is supplementary and confined to largely manual untrained tasks, leads to women's poor access to income. Patriarchal Attitude is another hindrance to the empowerment of the women. Ownership of properties in the name of women is a strong evidence of women's economic strength. An independent ownership is important in case of divorce or separation or widowhood. According to a recent study of Kerala, women's risk of physical violence from husbands is dramatically less if they own land or a house. Patriarchal attitude can be changed by exploring such directions. The gender based atrocities give a disgraceful life to women victim rather than to the culprit. In regard of heinous crimes against women, it can be seen as a very positive vision that instead of making every day new provisions to penalize the criminals some process has to be evolved and established for rehabilitation, health, education, social participation and self esteem for the victims of such crimes. It is necessary for the Government to run various women empowerment and advancement initiatives by adopting Business Process Reengineering in Government so that a protective and a positive discriminating environment for the women 
may be created in which they can explore their hidden potential for the upliftment of the society.

\section{LITERATURE REVIEW}

Socio- economic development and empowerment of the society highly depends on the women's contribution to the society towards the affirmative transformation. The attitude of the society is changing due to various motivational and supportive steps taken by the Governments, NonGovernment Organizations (NGOs), Self- Help Group (SHGs) and Volunteers. This women friendly and supportive environment empowers them for their growth which leads to the advanced and transformational changes in the society.

[1] describes the socio- economic status of women across the life course in New South Wales (NSW) in which the author explores women's socio-economic status as a concept that captures access to resources, but is multidimensional in nature. That is, socioeconomic status is more than just educational attainment, occupation or income alone.

[2] highlights the women status in India. The author describes the women are victims of illiteracy, purdah system, child marriage, widows ' remarriage, polygamy, gender based atrocities, sati system, denial of individuality. Women still depend on their husbands and in-laws for economy and nonrecognition of their economic contribution.

[3] The Cairo conference on Population and Development organized by United Nations called attention to women's empowerment as a central focus. The UNDP Human Development Report 1995 was focused to women's empowerment. Sustainability, Equality and Empowerment were emphasized.

[4]The author assumes that the violence against women shows that the men to be superior to women. This concept is socially accepted and in vogue but it is a result of a long standing power imbalance between men and women. Without the support of a common man, the efforts of government and voluntarily organizations are not enough. The lack of education and awareness are the most common reasons of violence against women. The reason in India is highly vulnerable because of the poor quality of life indicated by the rampant poverty, high under five mortality, lack of education, poor health status, high maternal mortality rate and high fertility rate. Various Governments are adopting state of art technology and best practices to overcome such issues. Governments implement Information and Communication Technologies (ICTs) to make the process of women empowerment feasible for socioeconomic development of women. The report [5] is to mine the outcomes and impacts of ICT policies and projects for women and, it also shows the impact of ICTs on Gender Social Relations. The Governments form policies for the empowerment of the women in regard of health, education, political participation and gender based violence. [6] As per the United National Development Fund for women (UNIFEM), the term women's empowerment means to aspire gender parity in the social and economic space, self-belief and controls in one's decision making and actions, develop the ability to become the agent of household and social change of existing gender biased order. The author describes the role of Information Technology in Women Empowerment. The various eGovernance initiatives have been implemented by Governments for women empowerment. Social schemes like health related schemes and poverty alleviation schemes are delivered by tagging them with Information Communication and Technology. The Cash Transfer scheme helped in women empowerment in Mexico. Health Sector Mobile penetration are helpful to provide better Reproductive Health Services.

[7] e-Governance is in essence, the application of Information and Communications Technology to government functioning in order to create 'Simple, Moral, Accountable, Responsive and Transparent' (SMART) governance.

[Digital India] Process Re-engineering Model of Digital India (DI) was launched on 2nd July 201 by Government of India with the vision of Digital India programme is to transform India into a digitally empowered society and knowledge economy. The Digital India programme has three vision areasDigital Infrastructure as a Core Utility to Every Citizen, Governance and Services on Demand, and Digital Empowerment of Citizens. DI initiatives provide better opportunities for women empowerment and advancement.

[9] Government Process Re-engineering (GPR) is all about review, re-looking and redefining the way Government needs to operate, interact, interface, and transact with its stakeholders in ever changing times.

GPR is more need of the hour for Government of Uttar Pradesh than a matter of choice anymore for all practical reasons. As per Census India 2011 [10], Uttar Pradesh is the most populous state of India. To serve such a huge population is not possible without the use of proper mechanism. Government needs to do implement business process re-engineering in their functions.

Uttar Pradesh state of India has formed various policies and schemes to work towards giving control to women over their own lives in terms of both resource and ideology which empowers them socially and economically. Government of Uttar Pradesh (GoUP) has adopted Business Process Reengineering [11] approach in Government Processes through various E- Governance initiatives for women empowerment which is necessary for the advancement and transformation of the society. 


\section{GOVERNMENT PROCESS RE- ENGINEERING E- GOVERNANCE INITIATIVES}

Government of Uttar Pradesh has adopted Business Process Re-engineering in their processes to achieve the best quality results and benefits of the schemes. The state of art technology and best practices have been adopted to achieve the same through e-Governance initiatives. Many of them are for both men and women but these initiatives are really changing the life of women drastically which empowers them digitally and improve their socioeconomic status, and breaks the traditional approach to treat women.

\section{A. Rani Laxmi Bai Mahila Samman Kosh Portal}

Government Process Re-engineering model of a social sector scheme 'Rani Laxmi Bai Mahila Samman Kosh (RLBMSK) Portal' for educationally, medically and economically empowering the victims or sufferers of dowry death, grievous hurt by acid attack, rape resulting in death or permanent vegetative state, rape, gang rape and various sexual assaults which can be considered as most heinous gender based crimes. If any case related with defined sections of heinous crimes came into the knowledge of police, it is the responsibility of the concerned police officer to lodge the First Information Report and upload a copy of FIR along with filling some entries at Rani Laxmi Bai Mahila Samman Kosh portal (victim need not to apply the same), a designated nodal police officer of Additional Superintendent rank digitally authenticate the FIR, then record automatically become visible in the inbox of authorized medical officer of the district and District Steering Committee. Authorized medical officer arrange medical examination of the victim timely and feed/ upload the medical report of victim authenticated by her digital signatures and forward it to District Steering Committee. Designated signatory of District Steering Committee obtain the approval of chairman in the prescribed format downloadable from portal along with signature of Police Superintendent, same would be scanned, uploaded, digitally signed and forwarded with the recommendation for payment to Finance Management Unit by District Probation Officer using portal's features. On the basis of the recommendations of District Steering Committee, state level FMU generates the demand through web portal and verifies the account details of the victim with PFMS response to prevent any kind of fraud. After completion of process FMU makes beneficiary and payment e-files with the help of Public Finance Management System and e-Treasury to transfer the funds directly into the accounts of beneficiaries, after successful transfer of fund into the accounts of victims, information is automatically sent to the login of Superintendent of Police and District Steering
Committee. This initiative ensures the educational, medical and economical empowerment of victim women without considering their caste, creed or economic level. The loss due to the atrocity cannot be cover up but the monetary and medical relief provided by GoUP alleviates the pain as well as it ensures victims that the Government always stands by victim women for their empowerment.

\section{B. Integrated Grievance Redressal System (IGRS- Jansunwai)}

IGRS is an integrated system for grievance redressal in UP to achieve the goal of good governance using latest technology. Women can freely and conveniently file any grievance, track the grievance lodged on all important platforms and receive response to their satisfaction both in terms of time and quality. Now women do not need to approach any grievance redressal authority for grievances. They can also give the feedback on the action taken against their complaint. IGRS provides a platform of time bound, qualitative, easy and convenient way of grievance redressal mechanism. Quick action on the grievances lodged by women may address the issues of domestic violence and other gender based atrocities against the women. It makes a protective and friendly environment that empowers the women for their rights.

\section{Scholarship Portal: SAKSHAM}

The educated women educate the family which educates the society. For the empowerment of the society, the educational empowerment of the girls is necessary.

The scholarship schemes play a vital role in socio economic growth and empowerment of girl in the society. SAKSHAM is the government process reengineered model of scholarships developed and implemented in Uttar Pradesh to interact, interface and transact with all the concerned stakeholders in a integrated and interoperable manner for disbursement of scholarship and fee reimbursement in transparent, time bound, effective and efficient manner, directly into the bank account of downtrodden students. SAKSHAM provides the financial support to girls for further studies.

\section{Integrated Pension Portal}

Pensions provide the financial security and stability to women for their financial and social empowerment. These schemes ensure them to live with pride and self esteem. Integrated Pension portal integrates Samajwadi Pension, Old Age Pension, Widow Pension and Handicap Pension. These schemes have given thrust to women empowerment drastically. Samajwadi Pension is to provide financial support to the head of poor families as well as social, physical health, economical upliftment of their family 
members. Old Age Pension provides financial assistance to elders who completed 60 years of age and living below poverty line. Widow Pension provides financial assistance to the elligible women who are living below poverty line. This scheme gives a social and economical life support to destitute. Handicap Pension provides the assistance to handicapped women for their upliftment and empowerment. This scheme uplifts and empowers the differently abled women for their social advancement.

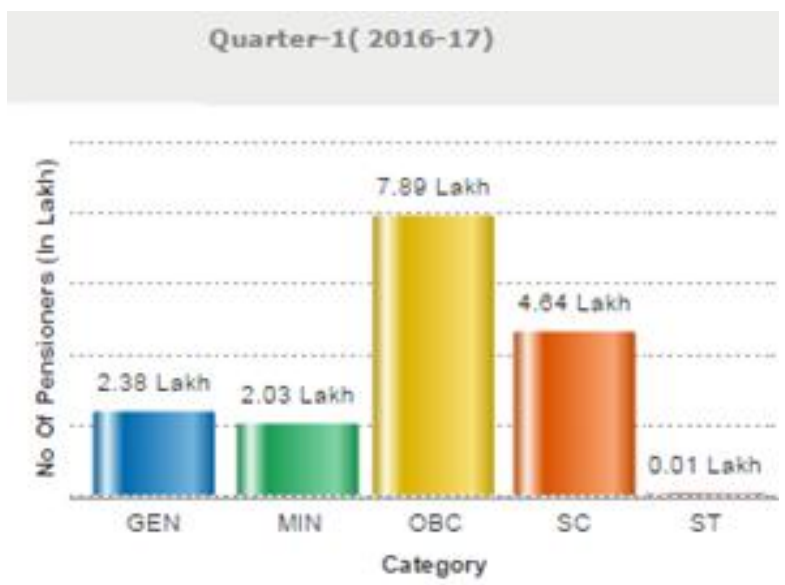

Figure 1: Beneficiaries of Widow Pension

\section{E. UPBhulekh}

Some studies prove that the risk of physical violence from husbands is dramatically less if they own land or a house. The Patriarchal Attitude is affected when the women own the property. Bhulekh 2.0 Cloud Based solution is a integrated model which empowers the women in terms of land details. The women can access their Record of Rights (ROR)/ Khatouni without approaching any government offices. Bhulekh 2.0 provides all the RORs online. The history of e-Governance in the form of Land Records in Uttar Pradesh begins with client server based Bhulekh software in 1998 to speed up the Record of Rights/Khatouni generation and reporting process. Then further evolution of process reengineering began for UP Bhulekh System. The state of art technology in the form of Cloud based Integrated BhulekhVer2.0 System which is an innovative model of Cloud Technology with Process engineering model of Land Records to disseminate and consolidate the relevant information regarding Land, the biggest cause of disputes resulting court cases. The portal provides the status of disputed and disputes free properties. This system empowers the women socially and helpful to change the patriarchal attitude.

\section{F. CSC 2.0}

To serve Government services to women population was not an easy task, it was full of complexities. Also, it was more cumbersome for the rural female population. But to serve Government services by the women to the women model has made this task easier. The process re-engineering in the delivery chain make the services available at citizen's doorstep. To give the thrust to the women empowerment in social and economical manner, Common Service Centers play a vital role in effective and efficient service delivery at their doorstep. By providing technical and digital assistance to open CSCs, women have started to earn in their locality by providing $\mathrm{G} 2 \mathrm{C}$ and $\mathrm{G} 2 \mathrm{~B}$ services to citizens and especially to women and making a reputation in the society which build up their confidence. Women are engaging themselves in paid works and the women work is now visible in the society, which is strengthening and empowering the society socially, economically and politically.

\section{IV. CONCLUSION}

The female population of Uttar Pradesh state is being empowered through process re-engineering approaches of various e- Governance initiatives. These initiatives not only empower the women but also strengthen the society. The best practices and state of art technology implemented in the state play vital role in the transformation of the society. The attitude of individual is changing and they are supporting the schemes associated with the women's socio economic development. Various e- Governance projects are focusing to overcome the loopholes in the existing system which hinders the women empowerment and advancement. Government emphasizes to open the door of opportunities for the women to show their potential. Implementation of Government's initiatives steer the traditional approaches to change the patriarchal attitude and provide an equal platform for women. Implementation of e- Governance initiatives for women's digital, social, economical and political empowerment and advancement to transform the society is really visible in Uttar Pradesh.

\section{REFERENCES}

[1] Jennifer Baxter and Matthew Taylor, "Socioeconomic status of women across the life course in NSW", Family and Community Services and Australian Institute of Family Studies, NSW Government, 2014.

[2] Women Status, "Socio-Economic Status of Women in India: A Review", available at http://shodhganga.inflibnet.ac.in/bitstream/1 0603/8562/7/07_chapter\%202.pdf (accessed on 12 Jun 2017)

[3] UP Planning Department, "Status of Women", available at http://planning.up.nic.in/apd/hdr-

2006/chapter-6.pdf (accessed on 14 Jun2017) 
[4] Waghamode R.H. et al., "Domestic Violence against Women: An Analysis", International Research Journal of Social Sciences, Volume 2(1), Jan- 2013.

[5] Samia Melhem and Nidhi Tandon, "Information and Communication Technologies for Women's SocioEconomic Empowerment", World Bank Group Working Paper Series, Jun- 2009.

[6] Saroj Kumari,"Role of Information Technology in Women Empowerment", Journal of Science and Management (LJSM), Volume 1, Jan- 2015.

[7] BPR, "Report on Business Process Reengineering for e-Governance Projects, Department of Administrative Reforms and Public Grievances, GoI, Nov- 2010.

[8] DI Portal, "Digital India", available on http://www.digital india.gov.in/ (accessed on 14 Jun 2017).

[9] GPR, "Reengineering Government, GPR", available http://www.skoch.in/images/stories/Governa nce_knowwledge/Reengineering\%20Govern ment $\% 20$ GPR_Government $\% 20$ Process $\% 20$ Reengineering.pdf (accessed on 14 Jun 2017)

[10] Census India 2011, "Primary Census Data Highlights-Uttar Pradesh", available at http://www.censusindia.gov.in/2011 census/PCA/PCA_Highlights/PCA_Highligh ts _UP.html (accessed on 14 Jun 2017)

[11] Dr. Saurabh Gupta and Sameer Rajan, "Study of Business Process Reengineering implemented in Uttar Pradesh for the Transformation and Advancement of the Society",InternationalJournal of Engineering Research and Technology (IJERT), Volume 6(6), Jun- 2017. 